\title{
Indoor Air Quality Assessment Based on Human Physiology - Part 3. Applications
}

\author{
M. V. Jokl \\ The proposed evaluation system allows something quite new: a) the assessment of the effect of each environmental component (constituent) \\ on the total environment level, b) accurate estimation of air volume for various locations, human occupations and sources of harmful gases. \\ Additional benefits are listed at the conclusion of this part.
}

Keywords: indoor air quality, odors, air changes estimation.

\section{Introduction}

In the area in question there are some problems arising in practical life, which have not been solved up to now. One of these is an assessment of the effect of each environmental component (constituent) on the total condition of the environment. In addition, there are new possibilities in the area of ventilation and ascertaining acceptable indoor air quality: the great variety of air volumes corresponding to each limit for unadapted and adapted persons, so that every situation that can occur in practice may be provided with the correct quantity of outdoor air. An attempt to list the benefits of the new system is presented at the end of this paper.

\section{A new prospect: the assessment of the effect of each constituent on the total environmental level}

Perhaps the greatest advantage of the new decibel unit is the possibility of a new type of microenvironment evaluation: first each constituent (component) is assessed separately, and then its effect on the whole environment is assessed. Decibels can also be a new basis for a constituent mutual interaction study.

The paper by [46] can be used for this purpose. Various constituents have different effects on the resulting environment: e.g. our health is more threatened by cold than by positive aeroions.

An increase of $6 \mathrm{~dB}$ represents a doubling of the sound pressure level, although an increase of about $10 \mathrm{~dB}$ is required before the sound subjectively appears to be twice as loud. The smallest change we can hear is about $3 \mathrm{~dB}$.

This is valid for the Weber-Fechner law and is also valid in a similar manner for the odor constituent. This, however, does not apply to the interaction of acoustic and odor or other constituents, as is evident from Rohles' [46] results.

The preliminary results from Rohles et al [46] are presented in Table 3.1. The hygrothermal component seems to be the most important (30\%). It is followed by illumination (24\%), acoustic (22\%), toxic (10\%), odor (8\%) and aerosol (6\%) constituents.

The influence of acoustic (AC) and odor (OD) constituents on the overall environment can be expressed as follows:
Table 3.1: The impact of some constituents and their parts on the perceived overall environment (according to Rohles et al [46])

\begin{tabular}{|l|r|c|}
\hline $\begin{array}{l}\text { Constituent } \\
\text { (or part of it) }\end{array}$ & $\begin{array}{c}\text { Impact } \\
{[\%]}\end{array}$ & $\begin{array}{c}\text { Constituent } \\
\text { factors }\end{array}$ \\
\hline Hygrothermal & 30.1 & HT $=0.30$ \\
\hline globe temperature & 15.8 & \\
\hline air streaming & 7.2 & \\
\hline air humidity & 7.1 & \\
\hline Odor & 7.5 & $\mathrm{OD}=0.08$ \\
\hline Toxic (tobacco smoke only) & 9.9 & $\mathrm{TX}=0.10$ \\
\hline Aerosol & 6.6 & $\mathrm{AE}=0.06$ \\
\hline Acoustic & 21.9 & $\mathrm{AC}=0.22$ \\
\hline loudness & 8.7 & \\
\hline noisy distractions & 8.6 & \\
\hline pitch of sounds & 4.6 & \\
\hline Lighting & 24.0 & $\mathrm{LI}=0.24$ \\
\hline brightness & 11.0 & \\
\hline glare & 7.9 & \\
\hline shadows & 5.1 & \\
\hline & & \\
\hline
\end{tabular}

$L_{\text {acoustic }}=$ AC $20 \log \frac{P}{20}=\frac{22}{100} 20 \log \frac{P}{20} \quad[\mathrm{~dB}]$

$L_{\text {odorCO }_{2}}=$ OD $90 \log \frac{\rho_{i \mathrm{CO}_{2}}}{485}=\frac{8}{100} 90 \log \frac{\rho_{i \mathrm{CO}_{2}}}{485}$

[dCd], [decicarbdiox]

or

$L_{\text {odor TVOC }}=$ OD $50 \log \frac{\rho_{i \text { TVOC }}}{50}=\frac{8}{100} 50 \log \frac{\rho_{i \text { TVOC }}}{50}$

[dTv], [decitvoc] (3)

where $\mathrm{AC}=0.22, \mathrm{OD}=0.08$ (22\% and $8 \%$ from Rohles's paper [46]). 


\section{Accurate ventilation for acceptable indoor air quality}

For this purpose BSR/ASHRAE 62-1989 R can be applied, i.e. the proposed system of $\mathrm{dCd}$ and $\mathrm{dTv}$ is compatible with this standard.

First, "Prescriptive Requirements", presented in Table 6.1 should be changed: instead of $R_{P}$ and $R_{B}$ air polution sources, $G_{P}$ (produced by human bodies and characterized by $\mathrm{CO}_{2}$ production) and $G_{B}$ (produced by building interior surfaces and characterized by TVOC production) should be used (see Table 3.2) calculated from formulas (4) and (5).

$$
\begin{aligned}
G_{P} & =\frac{2420-10}{10^{6}} R_{P}=0.21 \cdot 10^{-2} R_{P}\left[1 \cdot \mathrm{s}^{-1} \cdot \mathrm{p}^{-1}\right] \\
& =7.6 R_{P}\left[1 \cdot \mathrm{h}^{-1} \cdot \mathrm{p}^{-1}\right] \\
G_{B} & =\frac{580-10}{10^{3}} R_{B}=0.57 R_{B}\left[\mu \mathrm{g} \cdot \mathrm{s}^{-1} \cdot \mathrm{m}^{-2}\right]
\end{aligned}
$$

where $R_{P}\left[1 \cdot \mathrm{s}^{-1} \cdot \mathrm{p}^{-1}\right]$ and $R_{B}\left[1 \cdot \mathrm{s}^{-1} \cdot \mathrm{m}^{-2}\right]$ are original values presented in BSR/ASHRAE 62-1989 $\mathrm{R}$ in Table 6.1a.

Values of $\mathrm{CO}_{2}$ production from people or values of TVOC emanation within a building are prescribed for the estimation of minimum ventilation requirements or direct minimum ventilation requirements that are intended to achieve acceptable indoor air quality by dilution ventilation for various indoor spaces, when all other applicable re- quirements of this standard are met and the spaces are thermally comfortable. Requirements in this table are based on no smoking; refer to Appendix E when smoking or ETS is present. The prescriptive requirements for people, $R_{P}$ determined from $\mathrm{CO}_{2}$ production from people by Equation $R_{P}=G_{P_{C O}} / 3600\left(\rho_{i \mathrm{CO}_{2}}-\rho_{e \mathrm{CO}_{2}}\right)$

$\left(\rho_{e \mathrm{CO}_{2}}=310 \mathrm{ppm}\right.$, for other values see Table 3.3) are considered sufficient to satisfy adapted $\left(\rho_{i \mathrm{CO}_{2}}=2420 \mathrm{ppm}\right)$ and unadapted $\left(\rho_{i \mathrm{CO}_{2}}=1015 \mathrm{ppm}\right.$, other values see Table 2.1 p. 31 in Part 2) (visitors to the space) persons in the space. See Appendix B. The prescriptive requirements for the building, $R_{B}$, determined from TVOC building emanation in this table by Equation

$R_{B}=G_{B \text { TVOC }} / 3.6\left(\rho_{i \text { TVOC }}-\rho_{e \text { TVOC }}\right)$ (for adapted $\rho_{i \text { TVOC }}=580 \mu \mathrm{g} \cdot \mathrm{m}^{-3}$,

for unadapted $\rho_{i \text { TVOC }}=200 \mu \mathrm{g} \cdot \mathrm{m}^{-3}$, for other values see Table $2.3-$ p. $34, \rho_{e \text { TVOC }}=10 \mu \mathrm{g} \cdot \mathrm{m}^{-3}$, other values see Table 3.3) are for spaces that are designed, constructed, operated, and maintained according to this standard. Total rates in $1 \cdot \mathrm{s}^{-1}$ in the occupied zone for each space are to be determined from Equation 6-3. See Appendix A for further discussion of rationale. Simple system requirements are based on prescriptive requirements with assumptions made for people density and diversity, ventilation system efficiency, and filtration efficiency. See Appendix A.3 for details. Ventilation rates do not apply to spaces just after completion of construction or renovation. See Section 7 for purging of spaces prior to

\begin{tabular}{|c|c|c|c|c|c|}
\hline & \multicolumn{2}{|c|}{ Prescriptive Requirements } & \multicolumn{2}{|c|}{ Simple System Requirements } & \multirow[t]{4}{*}{ Notes } \\
\hline & People & Building & Outside Air & Supply Air & \\
\hline & $G_{P_{C O}}$ & $G_{B \text { TVOC }}$ & $R_{\mathrm{SB}}$ & $R_{\mathrm{SS}}$ & \\
\hline & {$\left[1 \cdot \mathrm{h}^{-1} \cdot\right.$ person $\left.^{-1}\right]$} & {$\left[\mu \mathrm{g} \cdot \mathrm{s}^{-1} \cdot \mathrm{m}^{-2}\right]$} & {$\left[1 \cdot \mathrm{s}^{-1} \cdot \mathrm{m}^{-2}\right]$} & {$\left[1 \cdot \mathrm{s}^{-1} \cdot \mathrm{m}^{-2}\right]$} & \\
\hline \multicolumn{6}{|l|}{ Miscellaneous spaces } \\
\hline Private toilet/bath & - & 14/fixture & 25/fixture & 25/fixture & $\mathrm{D}, \mathrm{E}$ \\
\hline Employee locker rooms & - & 0.77 & 1.4 & 1.4 & $\mathrm{E}$ \\
\hline Storage rooms & - & 0.34 & 0.60 & 0.60 & G \\
\hline Warehouses & - & 0.20 & 0.44 & 0.44 & $\mathrm{G}, \mathrm{H}$ \\
\hline Janitor's closet, trash room, recycling & - & 0.48 & 0.85 & 0.85 & $\mathrm{E}$ \\
\hline Shipping/Receiving/Distribution & - & 0.34 & 0.75 & 0.75 & G \\
\hline \multicolumn{6}{|l|}{ Public Assembly Spaces } \\
\hline Churches, temples & 23 & 0.20 & 4.2 & 15.0 & \\
\hline Legislative chambers & 23 & 0.20 & 1.9 & 5.0 & \\
\hline Courtrooms & 23 & 0.20 & 2.5 & 7.1 & \\
\hline Museums/Galleries & 27 & 0.48 & 1.9 & 2.5 & \\
\hline \multicolumn{6}{|l|}{ Retail } \\
\hline Sales floor (except as below) & 27 & 0.48 & 1.2 & 1.2 & \\
\hline Malls & 30 & 0.17 & 1.5 & 2.8 & \\
\hline Barber shop & 23 & 0.48 & 1.9 & 2.6 & $\mathrm{E}$ \\
\hline Beauty and nails salons & 38 & 0.77 & 3.3 & 3.3 & $\mathrm{E}$ \\
\hline
\end{tabular}
occupancy.

Table 3.2: Minimum requirements for ventilation (Adapted from BSR/ASHRAE 62-1989R Table 6.1a) 
Table 3.2: Minimum requirements for ventilation (Adapted from BSR/ASHRAE 62-1989R Table 6.1a)(continue)

\begin{tabular}{|c|c|c|c|c|c|}
\hline & \multicolumn{2}{|c|}{ Prescriptive Requirements } & \multicolumn{2}{|c|}{ Simple System Requirements } & \multirow[t]{4}{*}{ Notes } \\
\hline & People & Building & Outside Air & Supply Air & \\
\hline & $G_{P \mathrm{CO}_{2}}$ & $G_{B \mathrm{TVOC}}$ & $R_{\mathrm{SB}}$ & $R_{\mathrm{SS}}$ & \\
\hline & {$\left[1 \cdot \mathrm{h}^{-1} \cdot\right.$ person $\left.^{-1}\right]$} & {$\left[\mu \mathrm{g} \cdot \mathrm{s}^{-1} \cdot \mathrm{m}^{-2}\right]$} & {$\left[1 \cdot \mathrm{s}^{-1} \cdot \mathrm{m}^{-2}\right]$} & {$\left[1 \cdot \mathrm{s}^{-1} \cdot \mathrm{m}^{-2}\right]$} & \\
\hline Furniture, carpets, fabric & 27 & 1.34 & 2.5 & 2.5 & \\
\hline Pet shops & 27 & 2.48 & 4.7 & 4.7 & $\mathrm{E}$ \\
\hline Supermarket & 27 & 0.17 & 0.5 & 0.5 & \\
\hline Coin operated laundries & 30 & 0.20 & 1.0 & 1.2 & A \\
\hline \multicolumn{6}{|l|}{ Food and Beverage Service } \\
\hline Restaurant dining rooms & 23 & 0.48 & 2.7 & 6.2 & \\
\hline Cafeteria, fast food, dining hall & 23 & 0.34 & 2.3 & 6.1 & \\
\hline Bars, cocktail lounges & 23 & 0.48 & 39 & 9.9 & A \\
\hline Commercial kitchens & 30 & 1.62 & 3.7 & 3.7 & A, E \\
\hline Kitchenettes & 23 & 0.77 & 1.5 & 1.5 & $\mathrm{~A}, \mathrm{D}, \mathrm{E}$ \\
\hline \multicolumn{6}{|l|}{ Garage, Repair, Service Stations } \\
\hline Enclosed parking garages & - & 4.28 & 7.5 & 7.5 & $\mathrm{C}, \mathrm{E}$ \\
\hline Auto repair rooms & - & 4.28 & 7.5 & 7.5 & $\mathrm{~B}, \mathrm{E}$ \\
\hline \multicolumn{6}{|l|}{ Hotels, Motels, Resorts } \\
\hline \multicolumn{6}{|l|}{ Dormitories } \\
\hline Bedrooms (direct supply) & 19 & 0.43 & 25/room & $25 /$ room & $\mathrm{S}$ \\
\hline Living rooms (direct supply) & 19 & 0.43 & 25/room & $25 /$ room & $\mathrm{S}$ \\
\hline Bedrooms (indirect supply) & 19 & 0.43 & 40/room & 40/room & $\mathrm{S}$ \\
\hline Living rooms (indirect supply) & 19 & 0.43 & 40/room & 40/room & $\mathrm{S}$ \\
\hline Baths & - & $14 /$ room & 25/room & $25 /$ room & $\mathrm{D}, \mathrm{E}$ \\
\hline Dormitory sleeping areas & 19 & 0.20 & 0.93 & 2.4 & \\
\hline Lobbies/prefunction & 27 & 0.20 & 1.4 & 2.9 & \\
\hline Meeting rooms & 19 & 0.20 & 1.6 & 5.2 & \\
\hline Multi-purpose assembly & 27 & 0.20 & 4.6 & 12 & \\
\hline \multicolumn{6}{|l|}{ Office Buildings } \\
\hline Office space & 23 & 0.20 & 0.66 & 0.66 & \\
\hline High density open office space & 23 & 0.20 & 0.65 & 0.82 & \\
\hline Reception areas & 27 & 0.20 & 0.88 & 1.3 & \\
\hline Telecommunication/data entry & 27 & 0.20 & 2.5 & 5.9 & \\
\hline Conference rooms & 19 & 0.20 & 1.6 & 5.2 & \\
\hline Main entry lobbies & 27 & 0.17 & 0.59 & 0.59 & \\
\hline \multicolumn{6}{|l|}{ Public spaces } \\
\hline Corridors & - & 0.20 & 0.35 & 0.35 & \\
\hline Public restrooms & - & 14/fixture & 25/fixture & 25/fixture & $\mathrm{E}, \mathrm{M}$ \\
\hline Transportation waiting & 30 & 0.20 & 4.8 & 12 & \\
\hline Libraries & 19 & 1.05 & 2.0 & 2.0 & \\
\hline \multicolumn{6}{|l|}{ Sports and Amusement } \\
\hline Ice Arena (skating area) & - & 1.34 & 2.4 & 2.4 & $\mathrm{~J}$ \\
\hline Gymnasium, stadium (playing area) & 76 & 0.11 & 1.7 & 1.7 & $\mathrm{~J}$ \\
\hline
\end{tabular}


Table 3.2: Minimum requirements for ventilation (Adapted from BSR/ASHRAE 62-1989R Table 6.1a)(continue)

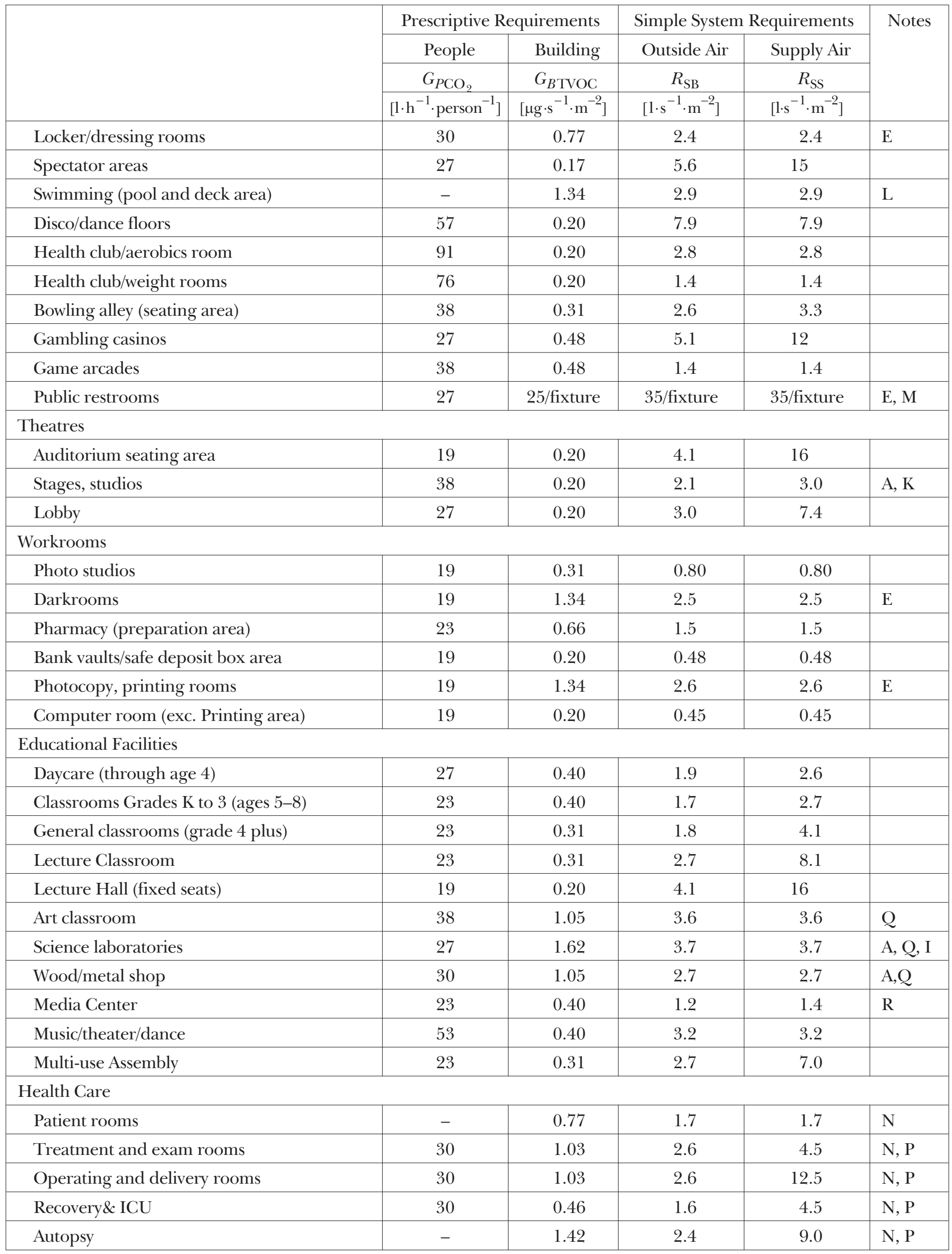


Table 3.2: Minimum requirements for ventilation (Adapted from BSR/ASHRAE 62-1989R Table 6.1a)(continue)

\begin{tabular}{|c|c|c|c|c|c|}
\hline & \multicolumn{2}{|c|}{ Prescriptive Requirements } & \multicolumn{2}{|c|}{ Simple System Requirements } & \multirow[t]{4}{*}{ Notes } \\
\hline & People & Building & Outside Air & Supply Air & \\
\hline & $G_{P \mathrm{CO}_{2}}$ & $G_{B \mathrm{TVOC}}$ & $R_{\mathrm{SB}}$ & $R_{\mathrm{SS}}$ & \\
\hline & {$\left[1 \cdot \mathrm{h}^{-1} \cdot\right.$ person $\left.^{-1}\right]$} & {$\left[\mu \mathrm{g} \cdot \mathrm{s}^{-1} \cdot \mathrm{m}^{-2}\right]$} & {$\left[\mathrm{l} \cdot \mathrm{s}^{-1} \cdot \mathrm{m}^{-2}\right]$} & {$\left[1 \cdot \mathrm{s}^{-1} \cdot \mathrm{m}^{-2}\right]$} & \\
\hline Physical therapy & 30 & 0.46 & 1.6 & 4.5 & $\mathrm{~N}, \mathrm{P}$ \\
\hline Waiting Room & 30 & 0.28 & 1.1 & 4.5 & $\mathrm{~N}, \mathrm{P}$ \\
\hline Isolation Rooms & - & 0.86 & 1.4 & 9.0 & $\mathrm{~N}, \mathrm{P}$ \\
\hline \multicolumn{6}{|c|}{ Correctional Facilities } \\
\hline Cells & 19 & 0.48 & 1.6 & 3.5 & $\mathrm{O}, \mathrm{P}$ \\
\hline Dayroom & 19 & 0.20 & 0.91 & 2.2 & \\
\hline Guard stations & 19 & 0.20 & 0.73 & 1.4 & \\
\hline Booking/waiting & 38 & 0.20 & 2.9 & 5.0 & $\mathrm{P}$ \\
\hline
\end{tabular}

Notes for Table 3.2

A Make-up for exhaust systems not included in rates listed. Provide listed rates or rate sufficient for make-up, whichever is larger.

B Stands where engines are run shall include systems for positive engine exhaust (direct exhaust pipe connection to exhaust system discharping to outdoors).

C A garage is unenclosed if open on two or more sides with those sides at least $50 \%$ open to outdoor. No more than $50 \%$ of make-up air shall be drawn from garage exit for garages more than 2 stories.

D Listed rate is for installed capacity controlled by occupant. For continuous ventilation system operation, reduce rate listed by $50 \%$.

E Rate listed shall be exhausted from the space. Exhausted air may be recirculated as allowed by section 5.4. Make-up air shall be any combination if directly supplied outdoor air, or air transferred from adjacent occupied and ventilated spaces.

F Ventilation required to optimize plant growth not included in listed values.

G Listed values may not be sufficient when stored materials include those having high VOC or other potentially harmful emissions. Use the analytical procedure in this case. (See section 6.4 and Appendix B).

$\mathrm{H}$ Listed rates do not account for combustion driven vehicles driven in space. Use the Analytical Procedure in this case. (See section 6.4 and Appendix B).

I Ventilation systems shall comply with NFPA 45-1991 and ANSI/AIHA Z9.5-1992.

$\mathrm{J}$ When internal combustion equipment is intended to be used on the playing surface for more than 10 minutes at a time (e.g., bike racing, truck shows), the listed rate shall be provided as exhaust from no more than $3 \mathrm{~m}$ from (both vertically and horizontally) the play area. Temporary use of internal combustion equipment, such as ice-surfacing machines, is acceptable provided a 5 -minute waiting period is allowed before occupants return to the field.
K Rate listed does not include special exhaust for stage effects, e.g., dry ice vapors, smoke.

L Rate listed is not intended to be sufficient for humidity control. Provide additional ventilation of mechanical system to remove moisture.

M Fixtures include both water closets and urinals.

N See "Guidelines for Control of Tuberculosis" (CDC, 1994) for other requirements.

O Allows for double occupancy per cell.

$\mathrm{P}$ The MSR for these spaces shall determined in accordance with the simple systems procedure (section 6.2.1) even if the prescriptive procedure is used to determine outdoor air rates.

Q Ventilation to these spaces may be broken into two components. Minimum rates determined using the category "General Classroom (grade 4 plus)" shall be provided at all times the room is expected to be occupied. This rate may be supplemented by exhaust air to provide the rates listed in the table for this category. The exhaust may be locally controlled so that it can be operated by occupants as required by the activity in the space. Air from these spaces may be recirculated only as allowed by section 5.4. Make-up air shall be any combination of directly supplied outdoor air, recirculated air, or air transferred from adjacent occupied and ventilated spaces.

$\mathrm{R}$ For high school and college libraries, use values shown for Public Spaces-Library.

$\mathrm{S} \quad$ Direct supply means the room is supplied with outdoor air via a supply grille (either directly or after being mixed with return air) or outdoor air is induced into the room by an exhaust system and the make-up outdoor air source is on the opposite side of the room from the point exhaust. All other designs are considered indirect supply systems. Systems for which the only source of make-up air is infiltration shall be considered indirect supply systems. [Examples of indirect systems include exhaust from an interior toilet room with make-up air drawn from the adjacent corridor.] 
Table 3.3: Outdoor TVOC and $\mathrm{CO}_{2}$ concentration

\begin{tabular}{|l|c|c|l|l|}
\hline \multirow{2}{*}{ Location } & $\begin{array}{c}\text { TVOC } \\
{\left[\mu \mathrm{g} \cdot \mathrm{m}^{-3}\right]}\end{array}$ & $\begin{array}{c}\mathrm{CO}_{2} \\
{[\mathrm{ppm}]}\end{array}$ & Source & Note \\
\hline \multirow{2}{*}{ At sea } & & $300-340$ & ICAO 1964 & \\
\cline { 2 - 5 } In towns, good air quality & 14 & 350 & EUR 14449 EN & TVOC converted decipol value \\
\cline { 2 - 5 } & $15-18$ & - & Ekberg 1993 & TVOC converted decipol value \\
\hline \multirow{2}{*}{ In towns, bad air quality } & 71 & $350-400$ & EUR 14449 EN & \\
\cline { 2 - 5 } & $23-98$ & - & Brown and Crump 1993 & \\
\hline
\end{tabular}

The introduction of $\mathrm{G}_{P}$ and $\mathrm{G}_{B}$ allows a) various levels of indoor air quality as presented in Table 2.1 (p. 31), Table 3.3, Fig. 2.1 (p. 33) and Fig. 2.3 (p. 36), and b) various levels of outdoor air quality as presented in Table 3.3 using the formulas (6), and (7) to be taken into account.

$R_{P}=\frac{G_{P}\left[1 \cdot \mathrm{h}^{-1} \cdot \mathrm{p}^{-1}\right]}{\left(\rho_{i \mathrm{CO}_{2}}-\rho_{e \mathrm{CO}_{2}}\right) 3.6} \quad\left[1 \cdot \mathrm{s}^{-1} \cdot \mathrm{p}^{-1}\right]$

$R_{B}=\frac{1000 G_{B}\left[\mathrm{~g} \cdot \mathrm{s}^{-1} \cdot \mathrm{m}^{-2}\right]}{\left(\rho_{i \mathrm{TVOC}}-\rho_{e \mathrm{TVOC}}\right)} \quad\left[1 \cdot \mathrm{s}^{-1} \cdot \mathrm{m}^{-2}\right]$

where

$\mathrm{G}_{P}$ and $\mathrm{G}_{B}$ are listed in Table 3.2 and Table 3.4, $\rho_{i \mathrm{CO}_{2}}=$ indoor $\mathrm{CO}_{2}$ concentration [ppm], see Table 2.1 (p. 31) and Fig. 2.1 (p. 33),

$\rho_{i \mathrm{TVOC}}=$ indoor TVOC concentration $\left[\mu \mathrm{g} \cdot \mathrm{m}^{-3}\right]$, see Tab. 2.3 (p. 34) and Fig. 2.3 (p. 36),

$\rho_{e} \mathrm{CO}_{2}=$ outdoor $\mathrm{CO}_{2}$ concentration [ppm], see Table 3.3,

$\rho_{e \text { TVOC }}=$ outdoor TVOC concentration $\left[\mu \mathrm{g} \cdot \mathrm{m}^{-3}\right]$, see Table 3.3.

With new values of $R_{P}, R_{B}$, calculated from formulas (6), (7) we can follow the way prescribed in BSR/ASHRAE 62-1989 R.

Table 3.4: TVOC emission rate according to various authors

\begin{tabular}{|c|c|c|c|c|}
\hline \multirow[t]{2}{*}{ Location } & \multicolumn{2}{|c|}{ TVOC $\left[\mu \mathrm{g} \cdot \mathrm{h}^{-1} \cdot \mathrm{m}^{-2}\right.$ floor $]$} & \multirow[t]{2}{*}{ Author } & \multirow[t]{2}{*}{ Note } \\
\hline & Mean & Range & & \\
\hline Existing buildings offices & 1550 & $100-4890$ & EUR $1444 \mathrm{EN}$ & Converted olf value \\
\hline working hours (9-11) & 360 & $132-691$ & Ekberg 1993 & \\
\hline night-time (5-7) & - & $90-467$ & Ekberg 1993 & \\
\hline Schools (class rooms) & 1550 & $620-2780$ & EUR 14449 EN & Converted olf value \\
\hline Kindergartens & 2060 & $1030-3810$ & EUR $14449 \mathrm{EN}$ & Converted olf value \\
\hline Assembly halls & 2570 & $670-6790$ & EUR 14449 EN & Converted olf value \\
\hline Dwellings & 720 & $360-1080$ & EUR 14449 EN & \\
\hline New PVC floor tiles & 795 & $450-1400$ & Brown et al 1993 & \\
\hline Low-polluting buildings (target values) & - & $260-510$ & EUR 14449 EN & Converted olf value \\
\hline $\begin{array}{l}\text { Solid flooring materials (vinyl, carpet, } \\
\text { chipboard) }\end{array}$ & \multicolumn{2}{|c|}{ typically below 55} & Crump et al 1997 & Emission rates constant \\
\hline Wall and ceiling materials & & & Crump et al 1997 & Emission rates constant \\
\hline plasterboard & \multicolumn{2}{|c|}{$\max 6$} & & \\
\hline 6-mm plywood & \multicolumn{2}{|c|}{$\max 10$} & & \\
\hline 15-mm plywood & \multicolumn{2}{|c|}{$\max 12$} & & \\
\hline bituminised fibre board asphalt & \multicolumn{2}{|c|}{$\max 30$} & Crump et al 1997 & Emission rates constant \\
\hline
\end{tabular}


Table 3.4: TVOC emission rate according to various authors

\begin{tabular}{|l|c|c|c|}
\hline Location & TVOC $\left[\mu \mathrm{g} \cdot \mathrm{h}^{-1} \cdot \mathrm{m}^{-2}\right.$ floor $]$ & Author & Note \\
\hline PVC skirting board & below the detection limit & Crump et al 1997 & \\
\hline polythene spacer & 4 when heated to $40^{\circ} \mathrm{C}$ & & Crump et al 1997 \\
\cline { 1 - 3 } rockwool (cavity wall) & below 15 & $\begin{array}{l}\text { Emission rates declined } \\
\text { slowly }\end{array}$ \\
\hline mineral wool (loft) & & & \\
\hline
\end{tabular}

\section{Conclusions - the benefits of using the decibel scale}

The advantages of the new proposed evaluation system can be summed up in the following items:

1. The undoubted benefit of using the decibel scale is that it gives a much better approximation to human preception of odor intensity compared to the $\mathrm{CO}_{2}$ and TVOC concentration scales. This is because the human olfactory organ (see [27]) reacts to a logarithmic change in level which corresponds to the decibel scale, where a change of $1 \mathrm{~dB}$ is approximately the same relative change everywhere on the scale.

2. The new decicarbdiox and decitvoc values also fit very well with the $d B$ values for sound, e.g. the optimal odor value of $30 \mathrm{~dB}$ corresponds to the ISO Noise rating acceptable value NR 30 for libraries and private offices. They can therefore be compared to each other.

3. It is possible, by comparing $\mathrm{dCd}$ and $\mathrm{dTv}$ values, to estimate, which component - $\mathrm{CO}_{2}$ or TVOC - plays a more important role and hence which sources of contamination are more serious.

4. The new units - decitvoc and decicarbdiox - can be a new basis for a constituent mutual interaction study (see earlier section).

5. The units dCd and dTv can be estimated by the direct measurement of TVOC and $\mathrm{CO}_{2}$ concentrations - instruments can be calibrated directly in the new units.

6. The units $\mathrm{dCd}$ and $\mathrm{dTv}$, as indoor air quality criteria, allow an optimal range definition and corresponding optimal ventilation rate estimations for unadapted and adapted persons by applying optimal limits to formulas (6) and (7).

7. The units allow an optimal range definition (so-called asthmatics optimal range) for persons with increased requirements (e.g. those allergic to indoor air quality, operators in airport control towers, power stations etc.) and corresponding asthmatic optimal ventilation rate estimations for unadapted and adapted persons by applying asthmatics optimal limits to formulas (6) and (7).

8. The unit allow the admissible range definition (for both healthy and allergic persons) and corresponding admissible ventilation rate estimations for unadapted and adapted persons by applying admissible limits to formulas (6) and (7).

9. The units allow definition of the SBS range (corresponding to the long-term tolerable range) and corresponding long-term tolerable ventilation rate estimations, by applying long-term tolerable limits to formulas (6) and (7).

10. The units allow the estimation of dangerous indoor air quality (corresponding to the short-term tolerable range, see Figs. 2.1 and 2.3, p. 40 and 43) and corresponding short term tolerable ventilation rate estimations by applying short-term tolerable limits to formulas (6) and (7).

11. The units allow the efficiency of air cleaners (and other indoor air-improving measures, e.g. using low polluting building materials) to be expressed, i.e. what is the decrease of air contamination after application.

12. The units allow the determination of the required ventilation rates depending on the various levels of outdoor air quality (see before).

13. The method developed is universal, it can also be applied to other environmental constituents (see Introduction of Part 1, p. 22).

\section{References}

[1] Air quality guidelines for Europe. WHO Regional Office for Europe, Copenhagen, 1987.

[2] Bencko, V.: Health risk of indoor air pollutants: a central European perspective. Indoor Environ, 1994, Vol. 3, p. 213-223.

[3] Berglund, B., Johansson, I., Lindvall, T.: The influence of ventilation on indoor/outdoor air contaminants in an office building. Environ Int, 1982, Vol. 8, p. 395-399.

[4] Berglund, B., Johansson, I., Lindvall, T., Lundin, L., Morath, C.: Air quality and symptoms in a sick library. In: Perry, R., Kirk, P. W. (eds.) Proc Indoor Ambient Air Quality Conf. Selper, London, 1988, p. 355-364.

[5] British Standard 5990. Direct Fired Air Heaters. British Standard Institution 1981.

[6] British Standard 6230. Direct Fired Air Heaters. British Standard Institution 1982.

[7] Broder, I., Corey, P., Pilger, C.: Influence of VOC on the wellbeing of workers in office buildings. In: VOC in the environment. Indoor Air International, London, 1993, p. 595-601.

[8] Brown, V. M., Crump, D. R.: Appropriate sampling strategies to characterise VOCs in indoor air using diffusive samplers. In: VOC in the environment. Indoor Air International, London, 1993, p. 241-249.

[9] BSR/ASHRAE Standard 62-1989R. Ventilation for acceptable indoor air quality. ASHRAE, Atlanta, 1989.

[10] Crump, D. R., Squire, R. W., Yu, C. W. F.: Sources and concentrations for formaldehyde and other VOC in the indoor 
air of four newly build unoccupied test houses. Indoor Built Environ, 1997, Vol. 6, p. 45-55.

[11] Dingle, P., Murray, F.: Control and regulation of indoor air: an Australien perspective. Indoor Environ, 1993, Vol. 2, p. 217-220.

[12] Dongen van, J. E. F., Wal van der, J. F.: Perceived indoor air quality, comfort and health in renovated dwellings with a balanced mechanical ventilation system. $5^{\text {th }}$ Int Conf. Indoor Air Quality Clim., 1990, Vol. 4, Inglewood, Aurora, p. 329-334.

[13] Ekberg, I. E.: Sources of VOC in the indoor environment. In: VOC in the environment. Indoor Air International, London, 1993, p. 573-579.

[14] Environmental health directorate: exposure guidelines for residental indoor air quality: A report of the Federal-Provincial advisory committee on environmental and occupational health. Ottawa, 1989.

[15] EUR 14449 EN:) Guidelines for ventilation requirements in buildings, report No. 11. Commission of European Communities, Luxembourg, 1992.

[16] Fanger, P. O.: Thermal comfort. Danish Technical Press, Copenhagen, 1970.

[17] Fanger, P. O.: Introduction of the olf and the decipol units to quantify air pollution perceived by humans indoors and outdoors. Energy Build, 1988, Vol. 12, p. 1-6.

[18] Fanger, P. O., Berg-Munch, B.: Ventilation requirements for the control of body odor. Proc. $2^{\text {nd }}$ Int. Congr. Build Energy Manage, Ames (Iowa), 1983.

[19] First Groop Space Flight. Izdatelstvo Akademii Nauk SSSR, Moskva, 1964, p. 156 (in Russian)

[20] First Space Flights of Man. Izdatelstvo Akademii Nauk SSSR, Moskva, 1963, p. 203 (in Russian)

[21] Guchman, A. A.: Introduction to the theory of similarity. Vyssaja Skola, Moscow, 1963 (in Russian).

[22] Guidance Note EH 40/90, HSE Occupational Exposure Limits of GB, London, 1990

[23] Hoskins, J. A., Brown, R. C., Lewy, L. S.: Current levels of indoor contaminants in indoor air in Europe: a review of real situations. Indoor Environ, 1993, Vol. 2, p. 246-256.

[24] IAQU: Odor evaluation as an investigative tool. Indoor air quality update, 1991, p. 10-13.

[25] ICAO: Manual of the ICAO Standard Atmosphere, ed 2. Int. Civil Aviation Organisation, Montreal, 1964.

[26] Jaakola, J. J. K., Heinonen, O. P., Seppanen, O.: The occurrence of common cold and the number of persons in the office room. $5^{\text {th }}$ Int. Conf. Indoor Air Quality Clim., 1990, Vol. 1, Inglewood, Aurora, p. 155-160.

[27] Jokl, M. V.: Microenvironment: theory and practice of indoor climate. Thomas, Springfield, Ill, 1989.

[28] Jokl, M. V., Leslie, G. B., Levy, L. S.: New approaches for determining ventilation rates: the role of sensory perception. Indoor Environ, 1993, Vol. 2, p. 143-148.

[29] Jokl, M. V.: Human Performance and Enviroment Level. Czech Technical University Publishing House, Prague, 2000.

[30] Jokl, M. V.: Healthy Housing. Academia, Prague, 2002 (in Czech).
[31] Jones, P. J.: Room air distribution and ventilation effectiveness in air-conditioned oftices. $5^{\text {th }}$ Int. Conf. Indoor Air Quality Clim., Inglewood, Aurora, 1990, Vol. 4, p. 133-138.

[32] Keskinen, J., Graeffe, G.: Continuous monitoring of air impurities in dwellings. Environ Int., 1989, Vol. 15, p. $557-562$.

[33] Levy, L. S.: Regulatory approaches to indoor air quality - an update of the European position. In: Lester, J. N., Perry, R., Reynolds, G. L. (eds.) Quality of indoor environment, Selper, London, 1992, p. 23-40.

[34] Loewenstein, J. C.: Study of the small-scale relations between indoor and outdoor pollution ( $\mathrm{SO}_{2} \mathrm{NO}_{X}$-particles) in a hospital in the Paris region. In: Bieva, C. J., Courtois, Y., Govaerts, M. (eds.) Present and future of indoor air quality. Elsevier, Amsterdam, 1989, p. 261-268.

[35] Measuring Sound. Naerum, Bruel and Kjaer Co. (DK 2850), 1984.

[36] Molhave, L.: Volatile organic compounds, indoor air quality and health. Proc. Indoor Air, 1990, Vol. 5, p. 15-33.

[37] Nordback, D., Bjornsson, E., Widstrom, J., Strom, G., Palmgren, U., Jansson, C., Boman, G.: Asthma symptoms in relation to volatile organic compounds and bacteria in dwellings. In: VOC in the environment. Indoor Air International, London, 1993, p. 377-386.

[38] Op't Veld, P. J. M., Slijpen, H. G.: The Dutch E'Novation Program: indoor air quality in dwellings before and after renovation. Air Intiltration Rev., 1993, Vol. 14, p. 15-18.

[39] Oseland, N. A.: A review of odor research and the new units of perceived air pollution. Build Res. Establishment Occasional Paper, 1993.

[40] Palonen, J., Seppanen, O.: Design criteria for central ventilation and air-conditioning system of offices in cold climate. $5^{\text {th }}$ Int. Conf. Indoor Air Quality Clim., Inglewood, Aurora, 1990, Vol. 4, p. 299-304.

[41] Parine, N.: The use of odor in setting ventilation rates. Indoor Environ, 1994, Vol. 3, p. 87-95.

[42] Pettenkofer, M.: Über den Luftwechsel in Wohngebauden (Air change in residential housing). Cottasche, Munich, 1858.

[43] Piade, J. J., Gerber, C., Fink, W.: Assessment of ETS impact on office air quality, part 2. In: Perry, R., Kirk, P. W. (eds.) Proc. Indoor Ambient Air Quality Conf., Selper, London, 1988, p. 594-601.

[44] Proctor, C. J., Warren, N. D., Bevan, M. A. J.: Measurement of environmental tobacco smoke in an air-conditioned office building. In: Bieva, C. J., Courtois, Y., Govaerts, M. (eds.) Present and future of indoor air quality. Elsevier, Amsterdam, 1989, p. 169-172.

[45] Reynolds, G. L., Lester, J. N., Percy, R.: Laboratory and field assessment of three techniques for suspended particulate determination. In: Lunau, F., Reynolds, G. L. (eds.) Indoor air quality and ventilation, Selper, London, 1990, p. $455-468$.

[46] Rohles, F. H., Woods, J. E., Morey, P. R.: Indoor environment acceptability: the development of rating scale. ASHRAE Trans 95, 1989, Vol. 1, p. 3197.

[47] Seifert, B.: Regulating indoor air. Proc. Indoor Air, 1990, Vol. 5, p. 35-39. 
[48] Sisakjan, N. M., Jazdovskij, V. I.: First space flights of man. USSR Acad. Sci., Moscow, 1963, (in Russian).

[49] Skov, P., Valbjorn, O., DISG: The 'sick' building syndrome in the office environment: the Danish town hall study. Environ Int., 1987, Vol. 13, p. 339-349.

[50] Smedje, G., Nordback, D., Edling, C.: Indoor climate in schools in relation to asthma and sick building syndrome. In: Indoor Air Pollution, Proc. Int. Conf., 1994, p. 245-248.

[51] Thorstensen, E., Hansen, J., Pejtersen, J., Clausen, G. H., Fanger, P. O.: Air pollution sources and indoor air quality in schools. $5^{\text {th }}$ Int. Conf. Indoor Air Quality Clim., Inglewood, Aurora, 1990, Vol. 1, p. 531-536.

[52] Wal van der, J. F.: Portable air sampler for measurements in aircraft and public buildings. In: Bieva, C. J., Courtois, Y.,
Govaerts, M. (eds.) Present and future of indoor air quality, Elsevier, Amsterdam, 1989, p. 371-378.

[53] Wal van der, J. F., Moons, A. M. M., Cornelissen, H. J. M.: The indoor air quality in renovated Dutch homes. $5^{\text {th }}$ Int. Conf. Indoor Air Quality Clim., Inglewood, Aurora, 1990, Vol. 2, p. 441-446.

Prof. Ing. Miloslav V. Jokl, DrSc.

phone: +420224354432

email: miloslav.jokl@fsv.cvut.cz

Department of Engineering Equipment of Buildings

Czech Technical University in Prague

Faculty of Civil Engineering

16629 Prague 6, Czech Republic 